\title{
Delaware's Dominance: A Peculiar Illustration of American Federalism
}

Robert Thompson

Georgetown University, thompson@law.georgetown.edu

This paper can be downloaded free of charge from:

https://scholarship.law.georgetown.edu/facpub/1980

https://ssrn.com/abstract=2978773

Robert B. Thompson, Delaware's Dominance: A Peculiar Illustration of American Federalism, in Can Delaware Be Dethroned? Evaluating Delaware's Dominance of Corporate Law (forthcoming) 


\title{
Delaware's Dominance: A Peculiar Illustration of American Federalism
}

\author{
Robert B. Thompson*
}

Who makes corporate law has often been as important as its substance. The traditional presentation accepts state law as the predominant source of corporate rules and focuses on the "race between the states" dimension of the "who makes corporate law" question. For the last half century or more the accepted wisdom has been that Delaware has won this race for corporation charters and the money that comes with it, although states and commentators probe for chinks in the Delawarean armor. In many ways, this discussion is still framed by the key question of corporate law from the 1960s and 1970s: is Delaware's dominance explained by a "race to the bottom" skewing corporate law in favor of management interests who influence state lawmaking at the expense of shareholders or by a "race to the top" with state law incorporating rules that reflect preferences made through markets. ${ }^{1}$ This race between the states, however, cannot be understood without examining two other dimensions - the extent to which we rely on markets or government for corporate rule-making and the federalism dimension of apportioning responsibility between federal and state governments.

For the first half of our country's history after independence, none of the three dimensions was of particular importance. Corporate law was almost entirely at the state level with some United States Supreme Court cases reinforcing the right of corporations

\footnotetext{
* Peter P. Weidenbruch Jr. Professor of Business Law, Georgetown University Law Center.

${ }^{1}$ See infra notes $x x-x x$.
} 
to own property, make contracts, and to sue and be sued that had been commonly extended to collective entities in English law and elsewhere. ${ }^{2}$ Government regulation of entities (e.g. their permitted purposes, size, and duration) were common and followed from the sovereign's capacity to create corporations. Things changed in the last decade or so of the nineteenth century. State authorization of corporations to own stock in other corporations and the decline of state ability to regulate foreign corporations opened the way for states to openly compete for corporations headquartered in neighboring states. The content of the state corporations statutes also dramatically changed. "Laissez faire" statutes in New Jersey in 1896, soon followed elsewhere, signaled a shift to private ordering and markets at a time when the decline of ultra vires, quo waranto and regulation of foreign corporations first made it possible for a state to attract substantial incorporation business from its neighbors. Some current illustrations of the race between the states, for example, bylaws limiting where suits can be brought, reflect this dimension as well. The regulatory impulse of the earlier corporations statutes, however, did not disappear. It simply moved to federal law, setting up the federalism dimension of the "who makes corporate law" debate.

This chapter examines the contemporary interaction of corporate law along these three dimensions with a particular focus on federalism. In the same way that we often frame the race between the states in the examples of the 1960s and 1970s, the concepts of federalism that we bring to the discussion date from the New Deal and focus on whether the federal government will preempt state corporate law, usually by adding regulation to

\footnotetext{
2 For more discussion of the ideas developed in this paragraph see, See Robert B. Thompson, Why New Corporate Law Arises: Implications for the $21^{\text {st }}$ Century, The Corporate Contract in Changing Times: Is Law Keeping Up? (forthcoming 2017 University of Chicago Press, Steven Davidoff Solomon, William Savitt \& Randall Thomas, eds).
} 
a space that state law has left to private ordering. ${ }^{3}$ Corporate law federalism is different than the classic constitutional doctrine of our history and bears only faint resemblance to contemporary federalism discussions in areas such as education, energy and environmental law. An "on-off "view of allocating law-making power between state or federal government has given way in other fields to a more nuanced view of interactive federalism. This chapter presents the richer and more nuanced space of $21^{\text {st }}$ century corporate law federalism that has some points in common with federalism discussion in other subject areas and some that reflect the particular history of the development of corporate law. The last section suggests how this federalism dimension influences the race between the states dimension of who makes corporate law in a way that essentially has locked Delaware's dominance in place.

\section{The Point of Inflection for "Who Makes Corporate Law"}

Delaware rose to preeminence in the incorporation market after a key point of inflection for corporate law. Fort the first half of American history (to date) corporate law moved through waves of significant changes, all focused in state law: acceptance of limited liability for shareholders, the rise of general incorporation statutes, a strong shift to director-centric corporate governance, and authorization of corporations' owning stock in other corporations, among others. ${ }^{4}$ Then around the turn of the $20^{\text {th }}$ century, Delaware quickly followed New Jersey in a move to a laissez-faire statute. In the time since that point state corporation law has been much more stable in the now familiar

\footnotetext{
${ }^{3}$ For discussion of traditional concepts of dual federalism see Part II infra.

${ }^{4}$ See infra, Part IA.
} 
Delaware approach of default rules that can be modified by the parties but providing a governance structure centralized in the board and management with only a limited role for shareholders. When Delaware and New Jersey abandoned the traditional state law regulation of corporate behavior at the end of the $19^{\text {th }}$ century, that regulatory impulse did not die, it just moved to federal law. Ever since, Delaware, and those other states who wish to compete with it, have remained free to focus on centralized governance and private ordering, adjusting as necessary to insure that the entity retained sufficient flexibility to adapt to new economic changes. If the result was that directors and managers got too powerful, federal law picked up the slack, first in antitrust law and labor and consumer regulation of corporate behavior and increasingly by federalization of parts of the traditional Delaware space of core corporate governance.

\section{A. American corporate law in the $18^{\text {th }}$ and $19^{\text {th }}$ century}

There were very few business corporations at the time of the founding of the American republic. ${ }^{5}$ The corporate form passed down from the king's government had been used mostly for religious or charitable purposes or quasi-public (bridge or turnpike) entities. Fundamental economic and financial changes as the industrial revolution spread increased the scale of business and the size of the market in which entrepreneurs could compete effectively. By the 1830s, manufacturing corporations exceeded those in banking, insurance, and public service and the number was growing. ${ }^{6}$ There was a greater

\footnotetext{
${ }^{5}$ Joseph Davis,

${ }^{6}$ Phillip A.. Blumberg, The Corporate Entity in an Era of Multinational Corporations, 15 DEL. J. CoRP. L. 283, 301 (1990).
} 
need for enterprises which assembled the capital from more than one person. ${ }^{7}$ There was a greater need for legal rule to reflect and facilitate these developments and to accommodate the political will evident in the Jacksonian era to democratize the availability of the corporate form.

Over the course of the nineteenth century, there were many dramatic shifts in corporate law:

- Limited liability for shareholders (and for officers and directors) became the legally provided norm (although liability for double the amount of money paid for shares was common even after limited liability was inserted into law); ${ }^{8}$

- General incorporation statutes as opposed to special chartering by the legislature spread through the middle decades of the nineteenth century (although here, too, the change was gradual, not a dramatic on-off switch, as many states continued special chartering alongside general incorporation until late in the century ${ }^{9}$ and in Delaware, for example, the number of special charters greatly exceeded those provided under the general statute) ${ }^{10}$

- Corporate law moved strongly toward centralized management, reflected in a shift from the importance of the general meeting of shareholders to broad powers for

\footnotetext{
${ }^{7}$ Shaw Livermore, Early American Land Companies, Their Influence on Corporate Development (Commonwealth Fund) (1939).

${ }^{8}$ Morton J. Horwitz, Santa Clara Revisited: The Development of Corporate Theory, 88 W. VA. L. REV. 173 (1986).

${ }^{9}$ Eric Hilt, Corporations Law and the Shift Toward Open Access in the Antebellum United States, National Bureau of Economic Research Working Paper \# 21195 (2015).

${ }^{10}$ Samuel Arsht, The History of Delaware Corporation Law, 1 DEL. J. CORP. 1 (1976).
} 
directors ${ }^{11}$ and a centralized structure that could accommodate the rising influence of middle management; ${ }^{12}$

- Late in the century, changes in corporate law permitted corporations to own stock in other corporations, permitting holding companies that facilitated companies doing business outside their state of incorporation when prior law had often prohibited such action. $^{13}$

All of these changes occurred in state law-one at a time, eventually spreading to most of the country. Federal incorporation was initially in some doubt under the constitution and seldom used. The United States Supreme Court irregularly took up issues related to corporations, for example Dartmouth College in $1819,{ }^{14}$ Bank of Augusta v. Earle in 1839 (that declined to find a constitutional right for corporations to operate outside their state of incorporation), ${ }^{15}$ and a series of constitutional cases after the Civil War that protected corporations' rights to contract, own property and sue and be sued. ${ }^{16}$

\section{B. The Appearance of the Three Dimensions of "Who Makes Corporate Law"}

By the late 1880 s all the elements of the modern corporation were in view, something that was not true a century before. But none of the three dimensions of "who makes law" had yet to gather a critical mass. In the 1890s, however, the competition and race between states for incorporation business accelerated, led by New Jersey. Its chosen

\footnotetext{
${ }^{11}$ E. Merrick Dodd, , Statutory Developments in Business Corporation Law 1886-1936, 50 HARV. L. REV. 27, 40 (1936).

${ }^{12}$ Alfred D. Chandler, Jr., The Visible Hand, The Managerial Revolution in American Business, 1977 (Belnap Press).

${ }^{13}$ See infra, notes $x x-x x$.

14

1538 U.S. ( 5 Pet.) 517 (1839).

${ }^{16}$ Margaret Blair \& Elizabeth Pollman, The Derivative Nature of Corporate Constitutional Rights, 56 WM. \& MARY L. REV. 1673 (2015).
} 
method of competition was to abandon the regulatory posture of prior corporate law in favor of what was termed "laissez faire" corporations statutes, thereby defining the regulatory/private ordering dimension. The federal government's continued adherence to a regulatory agenda as to corporations, first visible in antitrust laws, rules regarding employment and consumers, and limits on corporate political contributions, set up the federalism dimension of our topic. ${ }^{17}$

This point of inflection is noticeable and dramatic. Professor Joel Seligman termed it a "revolution wrought in the law of corporations" that "turned corporate law inside out." ${ }^{18}$ Professor (later Supreme Court Justice) Wiley Rutledge described this period as "destined eventually to reverse the historic policy of the states to place state policy fundamentally in opposition to that of the Federal government."19

New Jersey was the epicenter of this development, in part as its home state lawyers sought to take business from the big city just across the river. Amendments to the New Jersey corporations statute in 1888 and 1889 authorized corporations to own stock in other corporations. ${ }^{20}$ This power proved very helpful when state courts in Louisiana, New York and Ohio found trusts (an innovation of clever lawyers for Standard Oil in the early 1880s) violated their still restrictive corporations statutes not permitting operation outside the state of incorporation. ${ }^{21}$ James Dill, one of the lawyers pushing this early statute returned in 1896 to draft liberalizations of New Jersey's general incorporation act that removed limits on corporate duration, purpose, and size, explicitly

\footnotetext{
${ }^{17}$ New Corporate Law supra note xx at yy.

18 Joel Seligman, A Brief History of Delaware's General Corporation Law of 1899, 1 DEL. J. CORP. L. 249 (1976).

${ }^{19}$ Wiley D. Rutledge, Significant Trends in Modern Incorporation Statutes, 22 WASH. U. L. Q. 305 (1937).

${ }^{20} \mathrm{NJ}$ statutes

${ }^{21}$ Horwitz, supra note $x x$ at yy.
} 
authorized carrying on business in other jurisdictions, provided for mergers and consolidations, and added new management flexibility like permitting director amendment of bylaws. $^{22}$ New Jersey's incorporation revenues quickly grew, noticeably at the expense of New York, and other states followed its lead, including Delaware in 1899. New Jersey gave up some of its advantage when President-elect Woodrow Wilson pushed reform in the state's corporate law prior to leaving Trenton for Washington. ${ }^{23}$ As law students quickly learn, Delaware has long had the dominant position in the race among the states.

There were other reasons, of course, for this change. Dramatic changes in the economy made some see the emergence of large scale corporate concentration as necessary, if not inevitable. ${ }^{24}$ There was a decline in traditional corporate doctrines like ultra vires and quo warranto that had been used to cabin corporate acts and a similar shriveling of state efforts to assert control over foreign corporations. ${ }^{25}$ And there was widespread concern about overall changes in state law. Three American presidents in the early $20^{\text {th }}$ century called for federal incorporation; each failed. ${ }^{26}$ Calls for federal incorporation reappeared at the time of New Deal efforts to combat the Great Depression, but President Franklin Roosevelt and the Congress opted only for a partial federal response-securities laws that emphasized disclosure to protect investors and

\footnotetext{
${ }^{22}$ Charles Yablon, Historic Race Competition for Corporate Charters and the Rise and Decline of New Jersey, 1880-1910, 32 J. CORP. L. 355 (2007).

${ }^{23}$ Harold W. Stoke, Economic Influences on the Corporation Law of New Jersey, 38 J. Pol. Econ. 551-557 (1930).

${ }^{23}$ Rutledge, supra note $x x$ at $y y$.

${ }^{23}$ Horwtiz, supa note $x x$ at yy.

${ }^{24}$ Rutledge, supra note $x x$ at $y y$.

${ }^{25}$ Horwtiz, supa note $x x$ at yy.

${ }^{26}$ Robert B. Thompson, Robert B. Thompson, Preemption and Federalism in Corporate Governance:

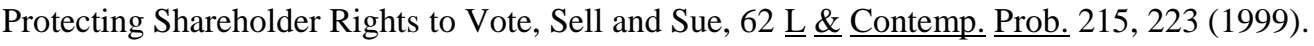


shareholders (and additional regulation of brokers, mutual funds and holding companies that increased social control over the financial sector). ${ }^{27}$

The New Deal pattern set the stage for the federalism dimension of "who makes corporate law" that continues to today. Congress can, if it wishes, (and given the outcome of the New Deal era Supreme Court decisions on the commerce clause) preempt state corporations laws. Even though Congress has not chosen to do so, it and the Securities and Exchange Commission have regularly imposed federal rules on corporate governance, usually motivated by a financial scandal or crisis that has pointed out failings of large corporations. For example, federal rules force public corporations to have mostly independent directors on their boards and audit, compensation and nomination committees made up entirely of such directors. ${ }^{28}$ State law, consistent with the dominant laissez faire mode, has no requirements for who can be directors. ${ }^{29}$ Federal law requires key officers to certify key financial documents; state law lacks such requirement or specification for any governance role for officers other than as the directors may direct. ${ }^{30}$ Federal law requires that shareholders be able to vote on executive compensation and to suggest other items for a shareholder vote (even though the outcome of all such votes are advisory only). ${ }^{31}$ Federal rules regularly use disclosure requirements to muscle

${ }^{27}$ Adam C. Pritchard \& Robert B. Thompson, Securities Law and the New Deal Justices 95 Va. L. Rev. 841-926 (2009).

\footnotetext{
${ }^{28}$ Sarbanes Oxleyy \& dodd Frank

${ }^{29}$ See Del.cod Ann. tit. $8 § 142$.

${ }^{30}$ Dodd Frank; \& Del. 142

${ }^{31} \S 14 A$ \& 17 CFR 240.14a-8.
} 
management toward a desired substantive result. ${ }^{32}$ Litigation under federal antifraud disclosure rules provides key governance constraints on managers. ${ }^{33}$

Mark Roe has suggested that Delaware's role in corporate law is at the sufferance of the federal government. ${ }^{34}$ Delaware is aware that if it goes too far, it may provoke a federal intervention. The result is a dance between the two key parties with the feds having the ultimate power given their constitutional preeminence. The next part suggests a more dynamic and less power-oriented description of federalism now visible in corporate law.

\section{Twenty-first Century Corporate Federalism}

While the outlines of corporate federalism as suggested by Roe and others are clear, in this part I describe how contemporary corporate federalism is less of the power approach of traditional dual federalism allocating realms between governments and more of interactive federalism providing room for multiple roles by different levels of government. The first part of this section describes the array of the current space in which federal and state governments are interacting in corporate governance. The second part suggests how contemporary discussions of federalism in other areas might shape the corporate federalism discussion.

\footnotetext{
32 Robert B. Thompson \& Hillary A. Sale, Securities Fraud as Corporate Governance: Reflections Upon Federalism, 56 VAND. L. REV. 859 (2003).

${ }^{33}$ Id.

${ }^{34}$ Mark J. Roe, Delaware's Competition, 117 Harv. L. Rev. 588 (2003).
} 


\section{A. The Contemporary Space in which Corporate Federalism Appears}

The interstitial way in which the President and Congress have chosen to have federal law interact with state corporate law over the last 80 years is visible in many examples. Many of them fit the template of traditional federalism, where courts are policing a line between federal and state domains, often finding insufficient justification to support federal occupation. ${ }^{35}$ This part first provides several prominent examples and then develops an alternative set that requires a different federalism description.

\section{Traditional Federalism Defining State vs. Federal Realms}

While federal law did not preempt state corporations statutes in the New Deal securities legislation, there was nevertheless the potential of substantial overlap between the two realms - shareholders who bought and sold securities and who were injured by misrepresentation related to those securities (often by the managers of the corporation) also suffered loss if the same or related action of those managers violated state law fiduciary duties. After federal courts implied private rights of actions under antifraud provisions of the Securities Exchange Act of 1934, courts had to resolve the relationship between state and federal law. Supreme Court decisions in the 1960s and early 1970s permitted a broad overlap. In Superintendent of Insurance v. Bankers Life \& Casualty Ins. Co,, for example, the Court stated that Congress did not seek to regulate "transactions which constitute no more than internal corporate mismanagement" but then permitted a federal action in a transaction that was essentially that. ${ }^{36}$ Six years later in Santa Fe Indus., Inc. v. Green, a Court whose membership had shifted since the earlier

\footnotetext{
${ }^{35}$ See dual federalism discussed in Part $b$ of this section.

${ }^{36}$ Supt. Of Ins. v. Bankers Life \& Casiualty co., 404 U.S. 6, 9-12 (1971).
} 
decision, applied a more conventional federalism analysis to a securities transaction overlapping with state corporate law, declining to permit a federal securities remedy and leaving the shareholders to their remedy under state law: "the result would be to bring within the Rule a wide variety of corporate conduct traditionally left to state regulation....Absent a clear indication of federal intent we are reluctant to federalize the substantial portion of the law of corporations that deals with transactions in securities, particularly where established state policies of corporate regulation would be overridden." 37

The Court in that same period followed a similar and traditional federalism analysis as to tender offer regulation, added to the federal securities law in 1968. Some disappointed bidders sought to use the stated purpose of the Act "to insure that public shareholders who are confronted by a cash tender offer for their stock will not be required to respond without adequate information" to attack defensives tactics by management. ${ }^{38}$ The Court declined to read the statute as going beyond disclosure to substantive fairness and lower courts declined to permit litigants to use this federal law or the commerce clause to challenge state laws that did not permit bidders a meaningful opportunity for success. ${ }^{39}$

The Court of Appeals of the D.C. Circuit has followed a similar traditional federalism approach in two opinions two decades apart that struck down rules promulgated by the SEC as intruding too much into state law. In a 1990 decision, the court considered an agency rule banning midstream adoption by a corporation of a dual

\footnotetext{
${ }^{37}$ Santa Fe Indus., Inc. v. Green, 430 U.S. 462, 4xx (1977).pin

${ }^{38}$ Schreiber v. Burlington Northern, Inc. 472 U.S. 1 (1985).

${ }^{39}$ Amanda Acquisition Corp. v. Universal Foods Corp, 877 F.2d 496 cert. denied 493 U.S. 933 (1989).
} 
class voting regime, for example, giving management a separate class of shares with 10 or more votes per share and insuring that the holder of such shares would control a majority of votes even while having made a much smaller percentage investment in the company's capital. ${ }^{40}$ The court rejected such a rule on federalism grounds, "The Commission would be able to establish a federal corporate law by using access to national capital markets as its enforcement mechanism. This would resolve a longstanding controversy over the wisdom of such a move in the face of disclaimers from Congress and with no substantive restraints on the power." ${ }^{41}$ Two decades later the agency passed a rule providing some qualifying individual shareholders the right to nominate a candidate for director to be included on the company's proxy. ${ }^{42}$ This time Congress had explicitly authorized such rule-making just before enactment of the rule. ${ }^{43}$ Even so, a panel of the same court struck down this rule for the agency's failure to adequately assess the economic effects of the new rule. ${ }^{44}$

Each of those examples reflects a federalism mindset focused on an "on-off" switch: there is a federal realm and a state realm and the judiciary is to umpire in which realm the particular action falls given the context and the statute enacted by Congress. ${ }^{45}$ A similar bright line approach is visible in an adjacent area when the conflict is between federal securities law and state securities law. From the initial passage of the federal securities act and for 60 years thereafter federal law permitted concurrent federal and

\footnotetext{
${ }^{40}$ The Business Roundtable v. Securities and Exchange Commission, 905 F.2d 406 (D.C. Cir, 1990).

41 Id at 412.

${ }^{42}$ Business Roundtable

${ }^{43}$ Dodd Frank section

${ }^{44}$ Business Roundtable

${ }^{45}$ See infra note $x x$.
} 
state regulation of securities issuances. ${ }^{46}$ In 1996, in response to issuer frustration with dealing with multiple levels of regulators, Congress reversed the statute, now preempting state regulation for "covered securities", a term defined to include most large issuers subject to federal regulation. ${ }^{47}$ A similar preemption occurred two years later as to state class actions based on allegations of misrepresentation if relating to covered securities. ${ }^{48}$ As with the examples discussed above, the common federalism approach is to assume the activity is in one realm or the other and to plumb the statute or policy to see which place it belongs. Such an approach reflects the dual federalism approach of the 1930s. ${ }^{49}$ While it could describe some issues of securities regulation, contemporary discussion is not an on-off switch but a more interactive analysis as developed in the following section.

\section{Interactive Federalism in the Corporate Space.}

More recent examples of federal-state interaction look somewhat different than those just described and show a more nuanced interaction between federal and state law. Congress has explicitly chosen not to embrace an exclusive and non-overlapping sphere in most areas of the corporate space so that a separate analytical framework in necessary to analyze federalism question.

\section{a. Misrepresentations in shareholder voting}

When the Supreme Court in J. I. Case v. Borak in 1964 found an implied private right of action under Rule 14a-9 for misrepresentations in proxy solicitations it expanded shareholder rights beyond what state law provided them vis a vis their managers and

\footnotetext{
4615 U.S. C. $\S 18$

47 SUSA

48

${ }^{49}$ See infra notes $x x-y y$.
} 
directors. ${ }^{50}$ Delaware's statute, then as now, had no explicit requirement for any disclosure when a shareholder vote was sought nor specific enforcement provision beyond general fiduciary duty. ${ }^{51}$ Even though the Court a decade and a half later rejected the Borak reasoning, it declined to question the actual holding of the case so that the federal remedy continues to be available for shareholders whose proxy is being solicited. ${ }^{52}$ So look what has happened: the federal presence has receded, at least substantively, while Delaware has fully adopted the important parts of 14a-9 law for itself and become the major presence in disputes relating to proxy disclosure.

Delaware courts first declared that directors' fiduciary duty includes disclosing "fully and fairly all material information within the board's control when it seeks shareholder action." ${ }^{53}$ In determining what is material, Delaware courts explicitly adopted the federal standard initially proclaimed in a Rule $14 \mathrm{a}-9$ context by the U.S. Supreme Court in TSC v. Northway,: a statement is material if "there is a substantial likelihood that a reasonable investor would consider it important in deciding how to vote." ${ }^{54}$ Delaware's Chief Justice Leo Strine, in an earlier opinion written while he was on the chancery court, explained the efficiency in not retracing issues already resolved by federal law, in the context of the adequacy of disclosure related to directors conflicting interest, one of core issues of Delaware corporate law:

Federal regulations and exchange rules address disclosure of this kind in a detailed manner that balances the costs of disclosing all past relationships against the need to give stockholders information about some prior

\footnotetext{
50 J.I. Case Co. v. Borak, 377 U.S. 426 (1964).

${ }^{51}$ See e.g. Arnold v. Society for Savings Bancorp, Inc. 650 A 2d 1270, 1277 (Del. 1994).

52 Touche Ross \& Co. v. Redington, 442 U.S. 560, 576-78 (1979).

${ }^{53}$ Stroud v. Grace, 606 A.2d 75, 84 (Del 1992).

${ }^{54}$ See Rosenblatt v. Getty Oil. Co., 493 A.2d 929, 944 (Del. 1985).
} 
relationships that, while not rendering directors non-independent of each

other, are important enough to warrant disclosure. Those bodies of authority should not be lightly added to by our law. ${ }^{55}$

If a shareholder has two remedies for disclosure violations, one at state law and one at federal law; which one would you pursue? It turns out Delaware has additional remedies beyond those available under Rule 14a-9. Revlon, for example, requires a board to get the best price when a company is up for sale ${ }^{56}$ Or perhaps Blasius might be available which can invalidate board defensive tactics that interfere with the shareholder franchise unless the board can show a compelling purpose. ${ }^{57}$ These state law remedies can be much more valuable to shareholders than the federal remedy as shown in a well-known Delaware case, In re Topps Company Shareholders Litigation. ${ }^{58}$ Not only did the shareholder plaintiffs get an injunction until there was corrective disclosure, but the court required the board to release a potentially higher bidder from a Standstill Agreement that had effectively locked that bidder out of the bidding. Not surprisingly, Rule 14a-9 suits are less often used, but the interaction between the two sets of laws has been instrumental to the evolution of a more complete remedy for shareholders.

Forum-shopping for litigation challenging mergers has recently created new space for disclosure litigation in federal courts. The number of merger deals generating litigation increased substantially in the years after 2008, reaching $96 \%$ of all deals in large corporations in 2013. ${ }^{59}$. Empirical findings that these lawsuits are typically settled without material benefit to the shareholders but with a significant fee to attorneys filing

\footnotetext{
${ }^{55}$ In re Netsmart Technologies, Inc. Shareholders Litigation, 924 A. 2d 171, 206 (Del. Ch. 2007).

${ }^{56}$ Revlon, Inc. v. MacAndrews \& Forbes Holdings, Inc., 506 A.2d 173 (Del. 1986).

${ }^{57}$ Blasius Indus., Inc. v. Atlas Corp., 565 A.2d 651 (Del. Ch. 1988).

58926 A.2d 58 (Del. Ch. 2007).

${ }^{59}$ (Cain et al. 2017)
} 
the case provoked concern about this pattern and various calls for reform. Perhaps the most visible change was push back from Delaware courts during 2015 and the January 2016 decision of the Delaware Court of Chancery, In Re Trulia. ${ }^{60}$ There the court announced a policy of disapproval of merger disclosure settlements that did not benefit shareholders but did compensate attorneys. Not surprisingly, there has been movement away from the Delaware courts to courts of other states or to federal courts for corporations incorporated under the laws of Delaware (and who therefore could bring suit there under the state law just discussed. Cain, Fisch, Davidoff Solomon \& Thomas, show an increased share of disclosure-only settlements occurring in federal courts -0 in six of eight years prior to 2010 rising to $18 \%$ of settled cases in 2015 and $31 \%$ in 2016 (although still a fairly small in absolute number of cases.). ${ }^{61}$

It seems unlikely that such disclosure=only settlements presage a significant increase in the federal presence shareholder disclosure and voting cases. And even here we see evidence of interactive federalism. Richard Posner, writing for the Seventh Circuit in a 2016 endorsed and applied Trulia to a federal case:

Delaware's Court of Chancery sees many more cases involving large transactions by public companies than the federal courts of our circuit do, and so we should heed the recent retraction by a judge of that court of the court's "willingness in the past to approve disclosure settlements of marginal value and to routinely grant broad releases to defendants and sixfigure fees to plaintiffs' counsel in the process. ${ }^{62}$

\footnotetext{
${ }^{60}$ In re Trulia, Inc. Stockholders Litigation, 129 A.3d 884 (Del. Ch. 2016).

${ }^{61}$ Cain et al 2016 year in review

62 In re Walgreen Co. Stockholder Litigation, 832 F. 3d. 718, 725 ( $7^{\text {th }}$ Cir. 2016)
} 


\section{b. Misrepresentations as to shareholder buying or selling}

The evolution of the 14a-9 remedy is more surprising in contrast to the adjacent evolution of the antifraud remedy available under Rule 10b-5. Each provides an antifraud remedy for shareholders-- the 14a-9 remedy in connection with shareholder decisions to vote and 10b-5 in connection with decisions to buy or sell. Voting and selling are two of the three core rights provides to shareholders under state law (suing being the third). ${ }^{63}$ Logic might suggest some general alignment across the two functions. Yet as shareholder voting suits have prospered in state law, making use of prior federal developments just discussed, the opposite has happened as to shareholder buying and selling. Shareholder class actions in federal law under Rule 10b-5 continue at a steady pace, even after the PSLRA in 1995 imposed more stringent restrictions of several of the elements required for plaintiff to recover and defendants continue to vigorously litigate each of the elements required for recovery. ${ }^{64}$ In contrast, Delaware precedent has made it very difficult to proceed with a class action under state law in a buying and selling situation. ${ }^{65}$ These cases are difficult to explain by reference to traditional federalism focused on blanket categories that are either state or federal.

\section{c. Changing the method for director voting}

There are other similar examples of the interactive element of corporate federalism. The usual state law threshold required for a director to be elected is a simple

\footnotetext{
${ }^{63}$ Robert B. Thompson, Preemption and Federalism in Corporate Governance: Protecting Shareholder Rights to Vote, Sell and Sue, $62 \underline{\underline{L}} \underline{\&}$ Contemp. Prob. 215-242 (1999).

${ }^{64}$ Cornerstone Research, Securities Class Action Filings-2016 Year in Review

${ }^{65}$ Malone v. Brincat 722 A. 2d 5 (Del 1988).
} 
plurality, i.e. more votes than the other candidate. ${ }^{66}$ But in most corporate elections, there is not any candidate other than the slate put forward by management. The SEC, pursuant to its authority under Section 14(a) to regulate proxies, has required that issuers include a box by which shareholders can "withhold" their vote. But even if a majority of shareholders withheld their votes, the candidate would still cross the plurality threshold. A shareholder .or a group of them could run their own candidate, but success there requires a shareholder to incur the expense of seeking proxies sufficient to get more votes than the management candidate, an expense that individual shareholders and even activists find daunting. As a more economical alternative that still provides a strong communicative message to management, shareholders have sometimes pursued "majority voting" bylaws that requires a candidate who gets a plurality but less than majority to resign and may provide that board must look elsewhere for a replacement candidate (or alternatively under some bylaws to permits the board to decline the resignation or reappoint the director.) ${ }^{67}$ Governance is a process that flows back and forth between state rules and federal rules and intentionally so. Federalism needs to adapt to such modern illustrations.

\section{d. Shareholder say on executive compensation}

The recently enacted federal requirement that shareholders vote on executive compensation has a similar effect. ${ }^{68}$ The federal requirement is precatory, that is to say advisory. Executive compensation is in the province of the board, as is the entire management of the business under Delaware $§ 141$. If the company's executive

${ }^{66}$ Del. Code ann. Tit $8 \$ 216(3)$ (directors elected by plurality of vote).

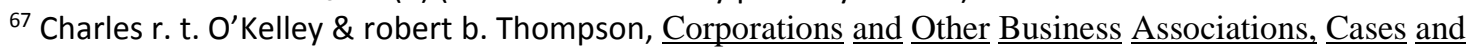
Materials, Wolters Kluwer Law \& Business, 8th Edition (forthcoming 2017) chapter 3.

${ }^{68}$ See supra notew $x x$. 
compensation plan gets less than a majority of shareholder votes, it can still go into effect. Directors get to do that as part of their comprehensive power. For this "say on pay" process to have the desired effect, directors must willingly take the advice of their shareholders or shareholders must be willing to use their vote at a subsequent meeting on an issue they do get to decide under state law- that of picking directors. It turns out that the mutual funds and other institutional investors that together own $70 \%$ or more of the shares in American corporations have been willing to use their vote against members of the compensation committee of corporations that fail to get sufficient support in the say on pay vote. Indeed, some institutional investors are willing to trigger such opposition if the company's pay plan gets a majority but less than a supermajority, say below 70 or $80 \%$. Of course, this subsequent shareholder vote on directors may be a "withheld" vote, subject to the variations discussed above unless the institutional investor is willing to run a slate of candidates in opposition to the company's slate. The role of proxy advisory firms, such as Institutional Shareholder Services (ISS), has been important in all of this in terms of putting pressure on boards. What we have, then, is a combination of state law rules on voting, federal law rules on advisory voting or withheld votes, and private ordering in the sense of institutional shareholders deciding the threshold at which they will employ each of their state and federal voting rights. ${ }^{69}$

\section{e. Removing staggered boards}

There are other examples as well. The rapid decline of staggered board over the last decade, after two earlier decades of seeming invincibility to shareholder efforts to get rid such a rule, reflects a similar combination to that just described. Staggered boards

\footnotetext{
${ }^{69}$ See Okelley \& Thompson, supra note $\mathrm{xx}$ at chapter 3.
} 
mean one third of the board is elected at each annual meeting so that at least two successive successful proxy campaigns must be run to get control of the board against the wishes of the incumbents. Few insurgents have been willing to tie up their capital for such a period. The state law rules that require boards to approve of any change to the articles before those changes are put to a shareholder vote effectively gave the board a blocking position against efforts to remove the staggered board provision. Even if shareholders succeeded in a getting a majority of votes on a $14 \mathrm{a}-8$ proposal seeking the end of staggered boards, the board could decline to take action, as discussed above. Only when enough institutional shareholders were willing to vote against non-agreeing directors at the next election for directors (or made an effective threat to do so) were boards willing to take the step to agree to changes in the articles. In the space of a few years staggered boards have practically disappeared from the largest American public corporations. $^{70}$

\section{f. Voting by institutional shareholders}

Federal regulators, initially the Department of Labor overseeing fiduciaries of retirement funds held for the benefit of workers, required those fiduciaries to vote those shares held in various plans, something that plan managers had not often done given that economic incentives seldom made voting worthwhile. ${ }^{71}$ The result was to grow the business of proxy advisory firms in helping funds meet such requirements and in turn to introduce a new player in corporate governance.

\footnotetext{
${ }^{70}$ Lucian Ayre Bebchuk \& Assaf Hamdani, Vigorous Race or Leisurely Walk: Reconsidering the Debate on State Competition over Corporate Charters.

${ }^{71}$ Paul Edelman et al. , Shareholder Voting in an Age of Intermediary Capitalism, 87 S. CAL. L. REV. 1359 (2014).
} 
This shared governance authority among state law corporate rules, various and often isolated federal rules, and the private ordering preferences of institutional investors, most of whom are agents for retirement plans, has dramatically changed corporate governance in the twenty-first century. In the examples just described, the corporate governance moved away from the default rule of traditional corporate law, but it was not a change in state statutory or common law that directly produced the result. Nor was it the explicit displacement of state law by federal law. It certainly did not reflect any race between different states. Most often, it was a (somewhat small) change in federal rules that generated greater activism by institutional investors to use one of the relatively few rights that traditional state law gives to investors. This is federalism not like what we have seen before in corporate law and requires a somewhat broader conception of corporate federalism to fully capture it.

\section{B. Contemporary Theories of Federalism as Reflected in the Corporate Law Context}

Until the New Deal, "dual federalism" dominated the discussion of allocating who makes law under the American constitutional system. State and federal governments were seen as having exclusive control of non-overlapping regions of authority; courts were charged with defining and monitoring the line. At the time of the point of inflection of state law and continuing through the New Deal, corporate law would have been considered within the state realm, whether the particular state took a laissez faire or more regulatory view toward the law that was enacted. After the economic and social 
disruption of the Great Depression, the executive and legislative branches greatly expanded the regulatory state including the first federal securities laws with various sections addressed to corporate governance. The Supreme Court's acceptance during President Franklin Roosevelt's second term of the broader federal presence in many areas led to a blurring of the "exclusive" regions for the federal government and the states so that "overlapping state and federal regulation has become the norm for many, if not most" areas of regulation. ${ }^{72}$ Thereafter, dual federalism was dead, but as Robert Schapiro observed, "its spirit continues to haunt contemporary discussions of federalism...the dualist conception of federalism as a line-drawing exercise persists." ${ }^{.73}$ The Court of Appeals' focus in the two Business Roundtable cases discussed in section IIA above suggests such a line-drawing focus. In contrast, the American discussion of federalism in recent decades has "has moved to a more dynamic or cooperative federalism approach in many areas that were formerly within the exclusive realm of the states, such as health, safety, and environmental protections." ${ }^{74}$ And, it might be said for our purposes, corporations. Various adjectives have been added to federalism to make this point and different authors have sometimes suggested different meanings for the same adjective. Cooperative federalism, for example, could mean the federal government establishing national standards or permitting requirements and then delegating to the states to administer the regulation including whether to grant or deny permits. ${ }^{75}$ But it often means more of a shared role. Alexandra Klass and Elizabeth Wilson argue that such

\footnotetext{
72 Robert A. Schapiro, From Dualism to Polyphony in Preemption Choice, 33, 40-41 (William W. Busbee ed. 2009).

${ }^{73}$ Robert A. Schapiro, Toward a Theory of Interactive Federalism, 91 lowa L. Rev. 243, 243 (2005).

${ }^{74}$ Alexandra B. Klasse \& Elizabeth J. Wilson, Interstate Transmission Challenges for Renewable Energy: A Federalism Mismatch, 65 Vand. L. Rev. 1801, 1830 (2012).

75 David Spence, Federalism, Regulatory Lags, and the Political Economy of Energy Production, 161 U. Pa.

L. Rev. 431, 470 (2013).
} 
concurrent regulation results "in a regulatory regime superior to what could be achieved by independent activity of each one" citing benefits form "plurality, dialogue, positive redundancy, greater regulatory competition, policy innovation and resistance to monopolies and group capture."76 For some, this approach to federalism pushes differences of opinion to be resolved in the political branches - for state governments for example to protect themselves in Congress, leaving courts to a more passive role. ${ }^{77}$ The Business Roundtable decisions discussed above might well fall short under this approach. What has sometimes been called Process Federalism emphasizes similar values, pushing as many decisions as possible into the Congressional sphere where states ae represented and using "clear statement rules" to incentivize more specific congressional findings and debate. ${ }^{78}$ State interests are better "protected by procedural safeguards inherent in the structure of the federal system than by judicially created limitations of federal power.",79

The recent examples in corporate law discussed above illustrate the rich and more nuanced interaction that results when there are multiple points of entry for different parties in interest seeking to resolve disputes in a collective enterprise. Even with a more passive judicial role, the process of Congress and the state governments setting forth rules would benefit from a more explicit discussion of which level of government is better suited to determine particular rights and rules. Many such discussions derive from a rational choice model, looking to methods of maximizing social welfare, aggregating preferences, and responding to market failures in private ordering. Consistent with the

\footnotetext{
${ }^{76}$ Alexandra Klass, State Standards for Nationwide Products Revisited: Green Building Codes and Appliance Efficiency Standards, 34 Harv. Envt. L. Rev. 335, 357 (2010).

${ }_{77}$ Schaprio, surpa note 3 at $x x$.

${ }^{78}$ See, Ernest Young, Stave Sovereign Immunity and the Future of Federalism, 1999 Sup. Ct. Rev. 1 (1999).

${ }^{79}$ Ernest Young, Protecting Member State Autonomy in the European Union: Some Cautionary Tales on American Federalism, 77 N.Y. U. L. Rev. 1612 (2002).
} 
federalism focus of this discussion, David Spence, drawing on work by Peter Menell \& Richard Stewart and William Eskridge \& John Ferejohn, among others, suggests four traditional rationales used to justify federal regulation of externalities and proceeds on the assumption that federal regulation is appropriate when one or more of these rationales applies. ${ }^{80}$

- regulation at the lowest element of government that geographically encompasses the costs and benefits of the regulated activities, a rationale that would justify federal regulation for pollution that spills over state boundaries;

- a focus on the capacity or willingness of state governments to regulate, for example, as in a race to the bottom context that has long been discussed in corporate law that if true would make reliance on state law questionable or if the jurisdiction is vulnerable to regulatory capture, which may be more likely in a smaller, concentrated jurisdiction than for the country as a whole;

- a need for uniform standards, one justification given for the preemption of state securities registration requirements where issuers seeking to raise money across multiple jurisdictions complained of the expense of having to comply with 50 sets of state rules as well as the federal standards;

\footnotetext{
${ }^{80}$ David B. Spence, Federalism, Regulatory Lags, and the Political Economy of Energy Production, $161 \mathrm{U}$. Pa. L. Rev. 431, 462 (2013) adapted from Peter S. Menell \& Richard B. Stewart, Environmental Law \& Policy 246-7 (1994) and William N. Eskridge \& John Ferejohn, The Elastic Commerce Clause: A Political Theory of American Federalism, 47 Vand. L. Rev. 1355, 1363-4 (1994).
} 
- if there is an important national interest in developing an asset or industry, for example when nuclear energy was first used and regulation was assigned to the national government.

The particular characteristics of the corporate setting influence the strength of each of these rationales. The most important distinguishing element in the corporate setting is the ability of corporations in any place in the country to choose their state of incorporation and thus the set of state law governance requirements. The internal affairs doctrine, which is widely accepted across American jurisdictions means that questions of internal corporate governance are decided based on the law of the state of incorporation, even if they are brought in federal court under diversity jurisdictions or in the courts of another state which has jurisdiction. This means only one state law matters, the corporation cannot be subject to 50 states as when it was selling securities prior to 1996 or when it sells products or engages with consumers across the country and would be adversely affected by overlapping rules from the various states. Thus the third rationale above will likely not show up in the corporate law context.

Corporate governance is no doubt important to American competitiveness and could support an important national interest justification for federal regulation, but the ability of corporations to choose their state of incorporation reduces the power of this argument. Even if one state, or many, had bad corporate laws, so long as corporations had the ability to choose a state with the preferred rules, whatever those might be, there would be little need for federal preemption (absent a prisoner's dilemma type situation caused by a race to the bottom discussed below). 
The first rationale, the spillover across state lines so the regulating state does not bear the full costs of the regulation (or the absence of regulation), costs which are felt by other states (for example downstream states in the case of air or water pollution) is less relevant in the corporate context than for fixed site pollution. To the extent that the regulating/incorporating state has a different mix of constituencies affected by the lawfor example mostly managers/directors and fewer investors/employees there is potential for a kind of externalization. This is usually discussed in corporate law if amplified by the possibility of a race to the bottom discussed immediately below.

The rationale most often used to support federal regulation in corporate law (and which is vigorously contested) is the second rationale-where the states could find themselves in a race to the bottom in a context where states would prefer more stringent regulatory standards, but cannot sustain any cooperative effort to maintain those standards in the face of temptation in the form of opportunity to attract corporations and revenue from other states (or not lose home state corporations and revenue to other states with more permissive corporate laws). The laissez faire changes that spread through state corporations laws beginning in the 1890s has suggested such a pattern to some. Professor William Cary's well-known article in the 1970s advocated federal incorporation standards as an antidote to the then 80 - year old pattern. ${ }^{81}$ Cary's article generated a

${ }^{81}$ William Cary, Federalism and Corporate Law: Reflections upon Delaware, 83 YALE L. J. 663 (1974). 
strong rebuttal from Professor Ralph Winter and others. ${ }^{82}$ The issue remains very much contested with multiple empirical studies on different sides of the issue.

What is important for this discussion is that federal law for more than 80 years has regularly intervened to displace parts of state corporations law that were seen as too strongly favoring management, for example. This is often depicted as a fight between directors/managers on one hand and shareholders on the other. But as Professor Roe has shown, this pattern can perhaps be better explained by constituencies outside the narrow set. ${ }^{83}$ Employees, creditors, consumers or the public, who have little chance to be a player in debate under state law go to Washington to seek a more receptive law-maker. Of course, managers and investors can be tempted to seek alliances in Washington DC as well. Even so the result of such appeals to the federal government pattern over the last 80 has usually produced legal change in the direction of more regulation and fewer restrictions on management.

\section{Federalism's Impact on the Current Race Between the States as to Who Makes}

\section{Corporate Law}

The previous parts present the combination of state and federal law that make up contemporary corporate law in the United States. Since the 1890s states have been able to compete for incorporations so that corporations can choose among the various state regimes for their governing law. Since New Jersey's 1896 corporations statute the

\footnotetext{
82 Ralph Winter, State Law, Shareholder Protection and the Theory of the Corporation, 6. J. LEGAL STUD. 251 (1977); See also Roberto Romano, Law as Product: some Pieces of the Incorporation Puzzle, 1 J. I. Econ \& Org. 225 (1985)/

${ }^{83}$ Roe supra, note $x x$ at yy.
} 
dominant approach for these state laws law has been decidedly deregulatory. The formerly regulatory pattern gave way to enabling statutes that preferenced private ordering over mandatory state rules, albeit with default rules that provided strong impetus for centralized control and specialization of function among various corporate constituencies. Federal law has never formally supplanted the organizational structure provided by the states, but has regularly displaced particular aspects of the state system. The usual federal approach evidences a different philosophy than the long-prevailing view at the state level. These rules typically override private ordering to place additional obligations on directors and officers or enhance the governance role of shareholders as a counterweight to centralized control. As described in Part IIA, the result has been a shared governance space among state law, federal law and private ordering. This part addresses how the particular way that federalism has developed in the corporate space affects the race between the states dimension of who makes corporate law.

Delaware's dominance of the race between the states is well-recognized. About $60 \%$ of publicly held companies in the United States are incorporated in that small midAtlantic state and if the measurement criteria were modified to those entities that are incorporated outside of their headquarters state, Delaware's share rises into the 80s. Delaware's dominance brings real benefits to the state. About $20 \%$ of the state's budget comes from incorporation fees, reducing what the state needs to ask of its residents to support its governmental operations. Its preeminence is shared by specific groups with the state. The legal industry, and particularly the Wilmington corporate bar, enjoys a prominence and a book of business that would be unexpected for a city of only 70,000. The corporate service industry and related professions including local universities have 
created distinctive expertise. Perhaps the most visible advantage is seen in its state judiciary. Most state supreme court justices have low visibility outside of their own state and trial judges even less. The chief justice and other members of the Delaware Supreme Court and the five members of the chancery court make most American corporate law. These judges are feted across the country and internationally, invited to conferences and provided publication, teaching and post-retirement opportunities that are not available to other state judges. ${ }^{84}$

Thus Delaware has good reason to care about its position in corporate law. It faces two sets of challenges. Another state might attempt to take Delaware's place, just as Delaware surpassed New Jersey in the last century. Alternatively (and both can happen at the same time) Delaware's preeminence can be eliminated or reduced by increased federal regulation. In theory challenges from other states could come from more than one direction i.e. states could push alternative governance rules that were either more or less regulatory than Delaware's position. New federal rules could likewise could move in a more or less regulatory direction. Modeling of the space would need to include the multiple possible paths.

In reality the choices are much more confined. Given the history already discussed the starting point creates path dependencies. Delaware and the other states start from a place that reflects a strongly deregulatory approach and at the same time a preference for centralized control. The federal government, when it intervenes, almost always does so via regulation and limiting centralized control. Given the constitutionally provided dominance of federal power, if used, in most contexts, including corporate law,

\footnotetext{
${ }^{84}$ Bebchuk \& Hamdani discuss this as ...
} 
Delaware can't go so far in preferring management that would wake the bear of federal action that would narrow the space within which state corporate law would be the governing rule.

While states desiring to take business from Delaware could theoretically change their laws to be more regulatory and limiting director power or to move in the opposite direction, the reality is asymmetrical. It is true that North Dakota's 2007 revisions of its corporations statute adopted an intentionally shareholder friendly-approach, but the state's effort have hardly been noticed by corporations thinking about reincorporation. ${ }^{85}$ Any state that wanted to increase the power of shareholders would be competing against an already large federal footprint that the state change would not likely move the needle of governance enough to attract the desired attention (and revenue) from corporations.

In contrast, Delaware has faced a considerably greater challenge from states desiring to make their corporations statues even more pro-management than Delaware. Several states, for example, have enacted mandatory staggered boards for their corporations thereby providing incumbents more insulation. Some states have also rejected Delaware's enhanced fiduciary duty standards for takeovers seen as having the potential to tie management hands in such a setting. Nevada has pushed further with changes such as permitting waivers of fiduciary duty of loyalty in its corporations, something that Delaware does not do. ${ }^{86}$

\footnotetext{
85 http://www.legis.nd.gov/assembly/60-2007/bill-index/bi1340.hyml.

${ }^{86}$ See generally, Michal Barzuza, Market Segmentation: The Rise of Nevada as a Liability-Free Jurisdiction. 98 Va. L. Rev. 935 (2012).
} 
These, of course, are the kinds of changes in state law that would seem likely to provoke federal intrusion. Mark Roe has pointed out a limiting factor that affects the race between states - the feds are much more likely to federalize Delaware law more than a state with a small market share. ${ }^{87}$ The result is to alter the risk to companies that could arise from future changes in a state's law once companies have reincorporated. Any state may go too far in a particular direction. The now-traditional pattern of federal law responding to perceived tilts in Delaware law limits the risk of such changes in Delaware, but not in the states with a smaller market share. ${ }^{88}$ The recent study by Ofer Eldar and Lorenzo Magnolfi provides support for this view, showing Nevada's growth has been concentrated in small firms with low institutional shareholder ownership, but not corporations more generally and suggesting Delaware would lose market share and millions in franchise taxes if it adopted the stronger management protections of Nevada. ${ }^{89}$

\section{Conclusion}

Determining "who makes corporate law" in $21^{\text {st }}$ Century America requires understanding the interaction of three overlapping dimensions - the competition between the states, the choice between regulatory law and private ordering, and the relation of federal law to state law under current theories of federalism. American corporate law scholars have tended to over emphasize the first and not updated their priors on the third. Thinking about federalism, reflected in the broader writings about the topic in the space beyond traditional corporate law, is much more interactive than at the time of Cary and Winter's initial writings on the race between the states. Numerous current examples of

\footnotetext{
${ }^{87}$ Roe, supra

88 Mark J. Roe, Delaware's Competition, 117 Harv. L. Rev. 588 (2003).

${ }^{89}$ Ofer Eldar \& Lorenzo Magnolfi, Regulatory Competition and the Market for Corporate Law, Yale Law \& Economics Working Paper \#528 (2016).
} 
corporate governance reflect an interaction of state law governance rules, federal regulation, and private incentives of participants that could not have been seen a decade ago. The particular effect on the race between the stats is somewhat surprisingfederalism has bolstered Delaware's position. 